УДК 004.046:004.032.6:004.382.75

( Ю. В. Ратушняк, аспірант, УАД, Львів, Україна

\title{
СТРУКТУРА ІНФОРМАЦІЙНОЇ ТЕХНОЛОГІЇ ПРОЕКТУВАННЯ ЕЛЕКТРОННИХ ВИДАНЬ ДЛЯ ПЛАНШЕТНИХ КОМП'ЮТЕРІВ
}

Розроблення моделей, методів і програмного забезпечення для автоматизації процесу проектування електронних видань для планшетних комп'ютерів є актуальним завданням. Здійснено декомпозицію (блоку А5) другого й (блоку А53) третього рівня контекстної діаграми функціональної моделі IDEFO процесу проектування електронних видань для планшетних комп'ютерів. Детально розглянуто функції (позначені блоками) й об'єкти (позначені стрілками) діаграм декомпозиції. Розроблено структуру інформаційної технології проектування електронних видань для планшетних комп'ютерів. Структура показує внутрішню організацію, взаємозв'язки компонентів системи. Запропонована інформаційна технологія складається 3 ієрархічно впорядкованих компонентів, а саме: процесу (АO), підпроцесів (A1A6), операцій (A51A55) і дій (A531A534).

Ключові слова: електронне видання; інформаційна технологія; планшетний комп'ютер; процес проектування; структура; функціональна модель; IDEFO.

\section{Постановка проблеми}

Проектування $\epsilon$ одним 3 етапів багатогранного процесу створення електронних видань (ЕВ), актуальність дослідження якого визначена декількома факторами. Насамперед, бурхливий розвиток інформаційних і комунікаційних технологій зумовив появу недорогих портативних планшетних комп'ютерів (ПлК) з сенсорним дисплеєм, які швидко стали популярним засобом взаємодії з інформацією серед користувачів ЕВ. 3 іншого боку, проектувальники ЕВ виявилися неготовими до стрімких змін. Вони зіткнулися 3 нестачею інформації стосовно умов використання й потреб користу- вачів ЕВ для ПлК і відсутністю апробованої концептуальної моделі системи (що поєднує абстрактні моделі проектувальника й користувача ЕВ для ПлК). Відомі технології, методи, техніки, підходи й апаратно-програмні засоби процесу проектування ЕВ стали неефективними, а подекуди й непридатними для виконання нових проектів зі створення EВ для ПлК. Сьогодні інформаційна технологія (IT) проектування ЕВ для ПлК набула динамічного розвитку. Моделювання цієї предметної галузі 3 використанням сучасних методів дослідження має важливе науково-прикладне значення. Процес проектування EB для 
ПлК ділять на декілька взаємопов'язаних етапів. Якщо систематично їх виконувати, відповідно до вибраної технології, то це дозволить значно підвищити ефективність порівняно зі стихійним просуванням до поставленої мети. Процес проектування ЕВ для ПлК важко уявити без творчої складової, тому про його повну автоматизацію не може бути мови, проте розроблення чіткого алгоритму та загальної структури процесу необхідні для полегшення одноманітної діяльності. Отже, зараз не існує науково обґрунтованих підходів щодо розв'язання цієї важливої задачі (розроблення IT проектування ЕВ для ПлК), що визначає актуальність і доцільність розроблення моделей, методів і програмного забезпечення для автоматизації процесу проектування EВ для ПлК, які послужили б основою для отримання якісного та конкурентного EВ.

\section{Аналіз попередніх досліджень}

Дослідженням методів, моделей і апаратно-програмних засобів автоматизації процесу проектування ЕВ займалися такі вчені: В. В. Браткевич, В. Є. Климнюк та О. І. Пушкар (аналіз етапів життєвого циклу мультимедійного видання) [1], В. А. Вуль (вивчення проблематики, пов'язаної з проектуванням EB) [2], В. М. Гасов й О. М. Циганенко (дослідження технології створення ЕВ) [3], Т. Ю. Киричок (систематизація відомостей щодо ЕВ) [4], В. М. Сеньківський (моделювання процесу проектування й розроблення EB) $[5,6]$ та інші. Загалом, ці дослідження стосуються лише ЕВ, як аналогів друкованих видань або інтерактивних EB, що призначені для використання на стаціонарних персональних комп'ютерах або ноутбуках.

У роботі [7] на основі методології функціонального моделювання штучних систем IDEFO $[8,9]$ започатковано розроблення структури IT проектування EB для ПлК, а саме: визначено мету створення, точку зору, цільову аудиторію функціональної моделі та межі моделювання (контекст); запропоновано ієрархію функціональних блоків системи (дерево вузлів); керуючись синтаксисом і семантикою IDEFO, побудовано контекстну діаграму моделі (рис. 1) й її декомпозицію першого рівня (рис. 2).

Щоб розробити структуру IT проектування ЕВ для ПлК, потрібно здійснити подальшу декомпозицію другого й третього рівня контекстної діаграми функціональної моделі IDEF0 процесу проектування EВ для ПлК.

\section{Мета роботи}

На основі методології функціонального моделювання штучних систем IDEFO розробити структуру IT проектування EB для ПлК.

\section{Результати проведених досліджень}

Інформаційна технологія (IT) проектування електронних видань (EB) для планшетних комп'ютерів (ПлК) - це процес 3 визначеною організаційною структурою, протягом якого група проектувальників, користувачів та всіх зацікавлених 


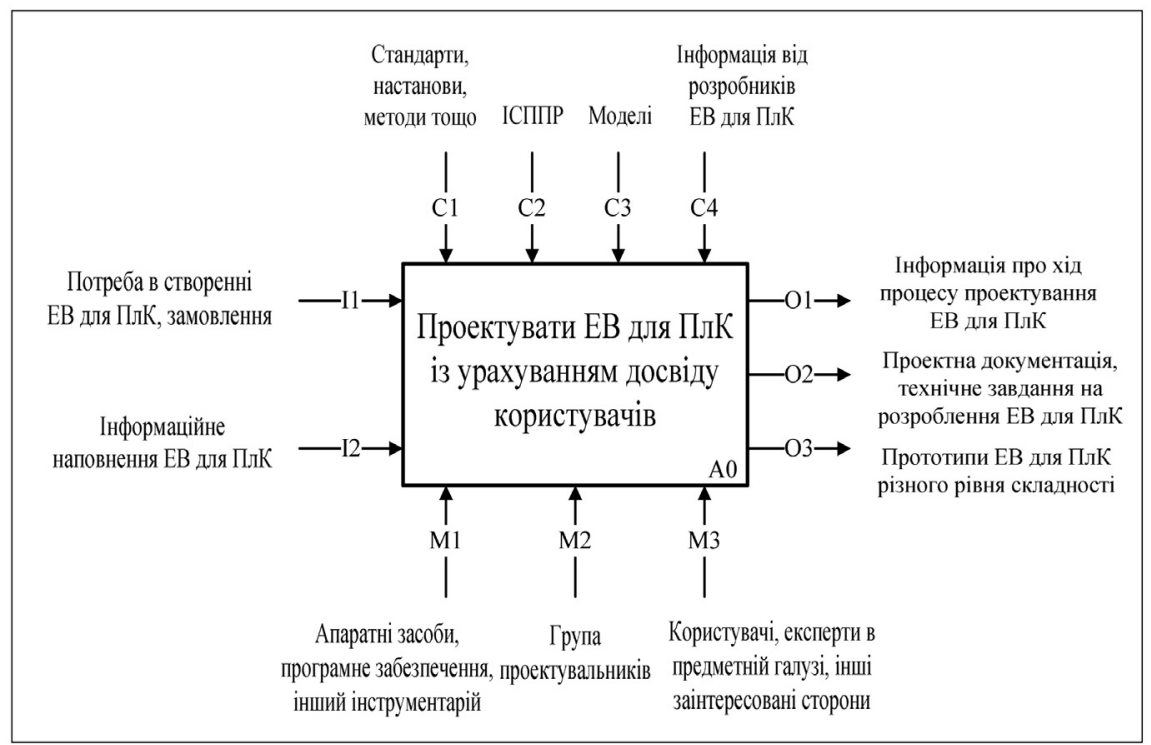

Рис. 1. Контекстна діаграма функціональної моделі IDEF0 процесу проектування електронних видань для планшетних комп'ютерів

сторін використовує певну сукупність методів і засобів отримання, обробки, зберігання й передавання первинної інформації для того, щоб перетворити її в новий інформаційний продукт. Структура IT проектування $\mathrm{EB}$ для ПлК являє собою ієрархічно впорядкований і взаємопов'язаний набір компонентів (функціональних блоків). Кожний рівень ієрархії позначає основні види функцій. Найвищий рівень ієрархії - це процес, що розглядають (проектувати ЕВ для ПлК), наступний рівень підпроцеси (див. рис. 2).

Для того, щоб продовжити розробляти ієрархічну структурну схему IT проектування ЕВ для ПлК слід здійснити декомпозицію блоку А5 (див. рис. 2) на основі методології IDEFO. Такий крок дозволить показати місце та роль автоматизованих систем проектування різноманітних прототипів EB для ПлК, залуче- них спеціалістів, керівника проекту в цьому підпроцесі, а також - інформаційних потоків, що уможливлюють перебіг функції А5. Перелік операцій, що необхідно виконати для досягнення мети функціонування блоку A5, стане третім рівнем ієрархічної структури IT проектування ЕВ для ПлК.

Отож, розглянемо детальніше функції, що зображені блоками на діаграмі декомпозиції другого рівня (рис. 3).

Блок А51. Протягом цієї операції керівник проекту зі створення EВ для ПлК виробляє директиви на керування операціями всього підпроцесу. Зворотний зв'язок є важливою передумовою для уточнення раніше прийнятих рішень.

Блок А52. Це творча операція, протягом якої група залучених до проектування спеціалістів, беручи до уваги специфікації умов використання й 


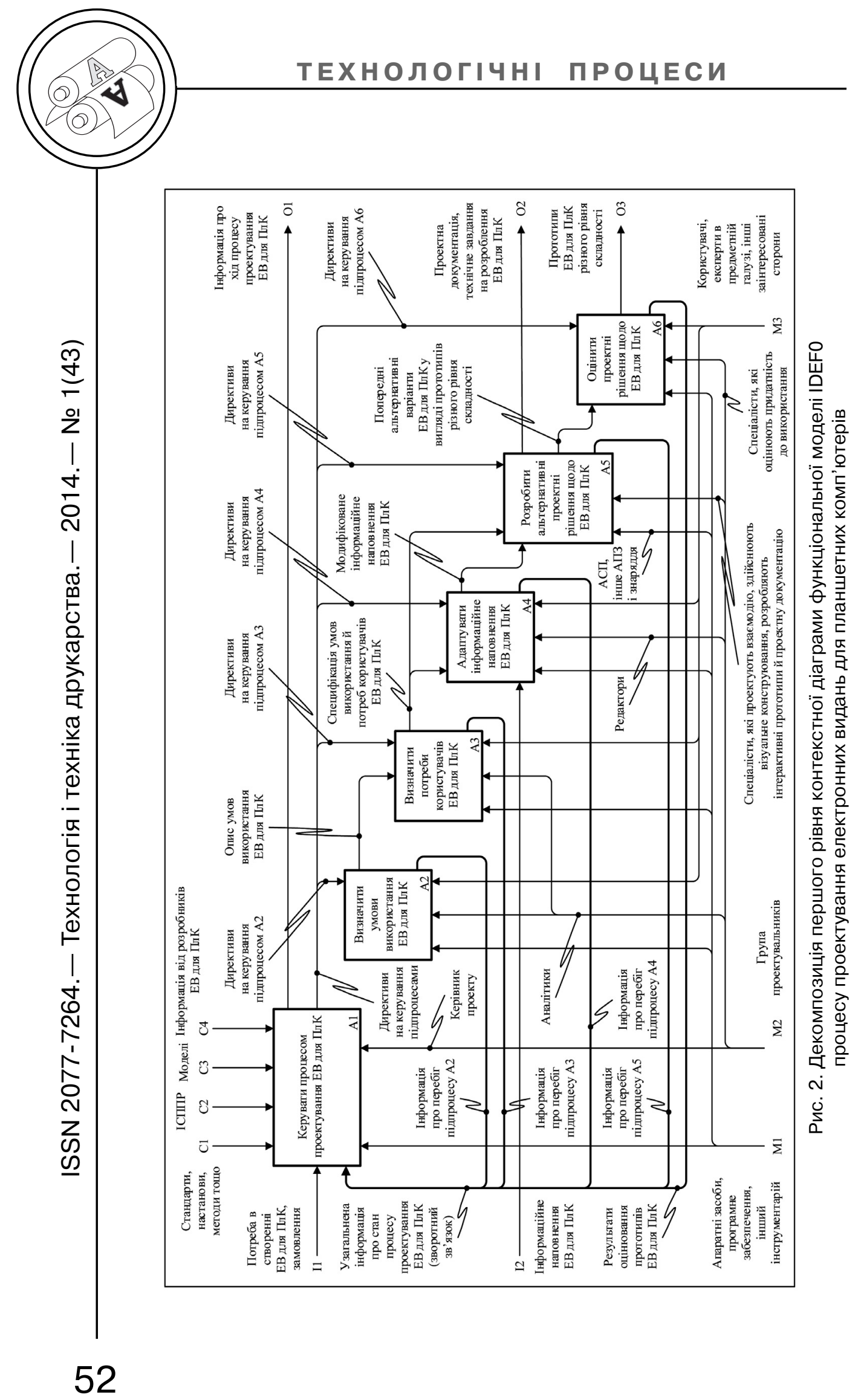




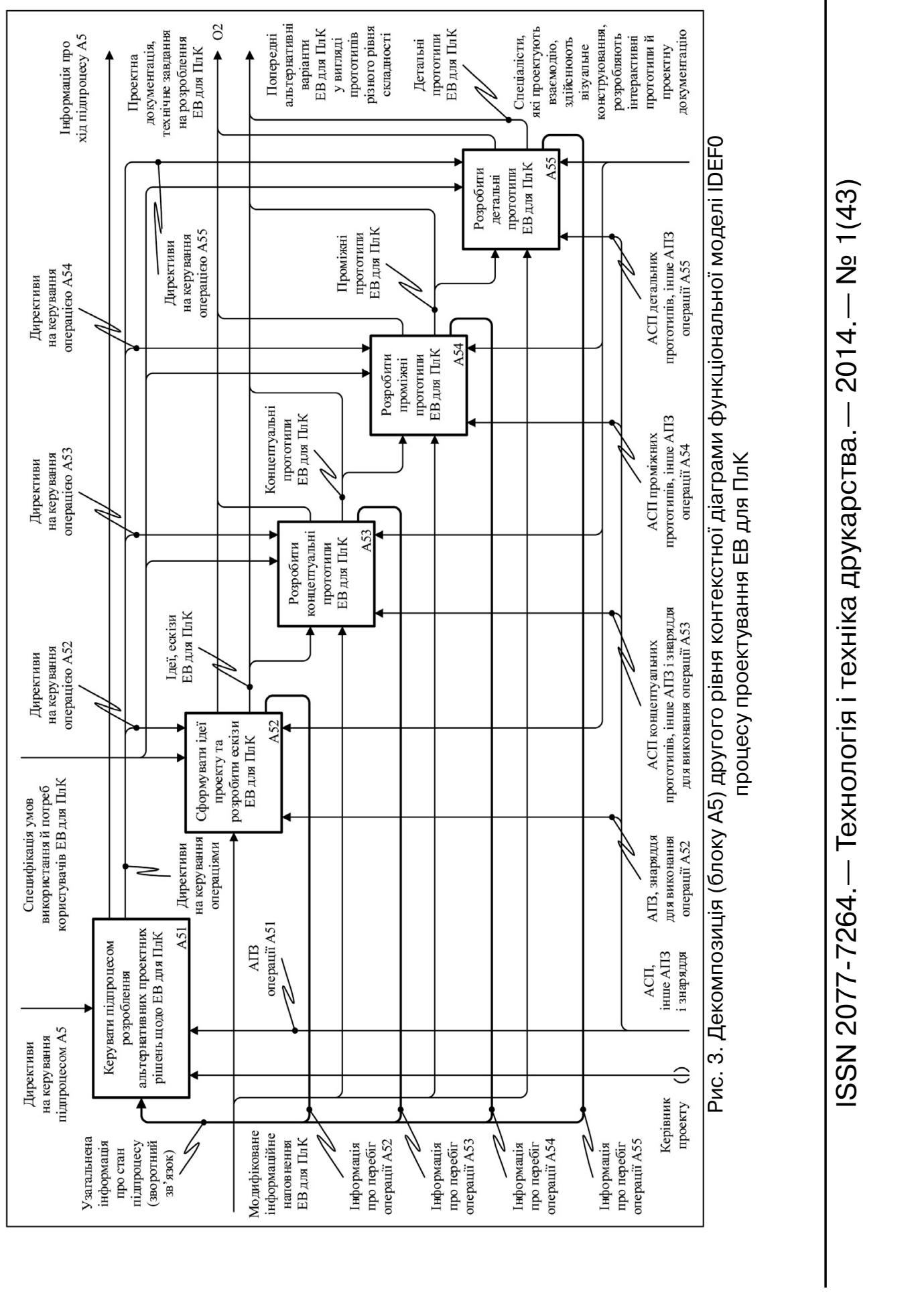


потреб користувачів ЕВ для ПлК, проводить колективне обговорення базових ідей проекту («мозковий штурм», англ. brainstorming). Після цього на основі ідей фахівці реалізовують декілька альтернативних варіантів анотованих ескізів майбутнього ЕВ для ПлК.

Блок А53. Протягом цієї операції команда задіяних проектувальників втілює в життя абстрактну модель ЕВ для ПлК у вигляді альтернативних концептуальних прототипів.

Блок А54. Протягом виконання цієї операції група спеціалістів визначає серед множини концептуальних прототипів ЕВ для ПлК оптимальний варіант і розробляє на його основі проміжні прототипи ЕВ для ПлК, яким характерний детальніше пророблений дизайн екранів (верстка, англ. layout) i навігаційна структура EB для ПлК. Саме на цьому етапі система починає набувати вигляду, що характерний розробленому ЕВ для ПлК.

Блок А55. Протягом цієї операції таж сама група проектувальників, яка була задіяна в попередніх операціях, розробляє детальні прототипи ЕВ для ПлК. Кінцевий макет системи візуально повністю схожий на повноцінне EВ для ПлК, але має суттєво обмежену функціональну складову. Детальні прототипи зазвичай виконують для невеликої частини складної в реалізації системи, оскільки це завдання потребує високих ресурсних затрат і тривале в часі.

Розглянемо детальніше попередні альтернативні варіанти EB для ПлК у вигляді прототипів різного рівня складності (описові інформаційні потоки), що отримують на виходах функціональних блоків А52, А53, А54, A55 (ці об'єкти зображені стрілками на рис. 3). Зауважимо, що для забезпечення процесу розроблення EВ для ПлК не завжди виникає потреба в створенні всіх видів прототипів системи, що проектують (концептуальних, проміжних, детальних). Зазвичай достатньо сформованих ідей та розроблених ескізів і розкадровок ЕВ для ПлК, а також декількох концептуальних прототипів ЕВ для ПлК для того, щоб уточнити найважливіші й оригінальні елементи майбутнього ЕВ для ПлК. Остаточне рішення щодо кількості необхідних прототипів ЕВ для ПлК і відповідно повноти потрібної проектної документації й технічного завдання на розроблення EB для ПлК приймає керівник проекту після аналізу всієї доступної інформації по даному питанню.

На виході блоку А52 (див. рис. 3) отримують множину альтернативних проектних рішень у вигляді анотованих чорнових ескізів ЕВ для ПлК та списку ідей стосовно процесу розроблення EВ для ПлК. Оцінку запропонованим ідеям і ескізам ЕВ для ПлК дають на основі обговорення та рецензування групою самих проектувальників, а при потребі залучають до цього процесу інші заінтересовані сторони.

На виході блоку А53 (див. рис. 3) отримують декілька концептуальних прототипів ЕВ для ПлК і визначають можливість їх реалізації в процесі розроблен- 
ня ЕВ для ПлК. Спеціалісти, які оцінюють придатність до використання прототипів EВ для ПлК за участі заінтересованих сторін здійснюють оцінку й порівняння альтернатив на основі розгляду розкадровок паперових прототипів ЕВ для ПлК і базових структурних інтерактивних прототипів ЕВ для ПлК.

На виході блоку А54 (див. рис. 3) одержують проміжні прототипи ЕВ для ПлК з проробленою логічною навігаційною структурою й візуальним дизайном екранів. Проміжні прототипи охоплюють зразки ЕВ для ПлК від орієнтовних до високоточних, а в деяких випадках i повністю інтерактивні макети 3 високоточною візуальною складовою. У результаті оцінювання проміжних прототипів (з обов'язковим залученням заінтересованих сторін) обирають серед альтернативних варіантів одного кандидата для подальшого уточнення та удосконалення, але без зміни основної концепції, що в ньому закладена.

На виході функціонального блоку A55 (див. рис. 3) дістають детальні структурні прототипи і (або) високоточні інтерактивні макети EВ для ПлК. Таким прототипам EB для ПлК характерні повністю визначений дизайн 3 детально описаною поведінкою користувача, зовнішній вигляд тощо. Остаточно доопрацьовують детальні прототипи ЕВ для ПлК на основі результатів оцінки придатності до використання, яку проводять відповідні спеціалісти разом з заінтересованими сторонами.

На рис. 3 видно, що директиви на керування операціями
(A52, A53, A54, A55) виробляє в результаті прийняття рішень керівник проекту зі створення EВ для ПлК (обмежувальна й керівна інформація). Ітераційне виконання підпроцесу A5 (розробити альтернативні проектні рішення щодо ЕВ для ПлК) забезпечують завдяки узагальненій описовій інформації, що поступає на вхід функціонального блоку A51 (зворотний зв'язок). На основі описової інформації про перебіг операцій (A52, A53, A54, A55), що надходить від кожної операції підпроцесу А5 приймають рішення про подальші дії кожного учасника групи проектувальників, задіяних на даному етапі. Наприклад, припинити виконувати операцію й перейти до іншої чи навпаки повторно виконати поточну операцію або перейти до попередньої, якщо на даному етапі отримані незадовільні результати.

Позначені на рис. 3 автоматизовані системи проектування (АСП) концептуальних, проміжних, детальних прототипів ЕВ для ПлК, а також інше апаратнопрограмне забезпечення вибирають залежно від методів, технік і підходів, що будуть використовувати для розроблення конкретних прототипів EВ для ПлК.

Тепер, розглянемо детальніше функції, що зображені блоками на діаграмі декомпозиції третього рівня (рис. 4).

Як уже зазначалося вище, достатній набір прототипів необхідний для того, щоб забезпечити процес розроблення ЕВ для ПлК повинен містити концептуальні прототипи системи. Таким чином, перелік дій, який 


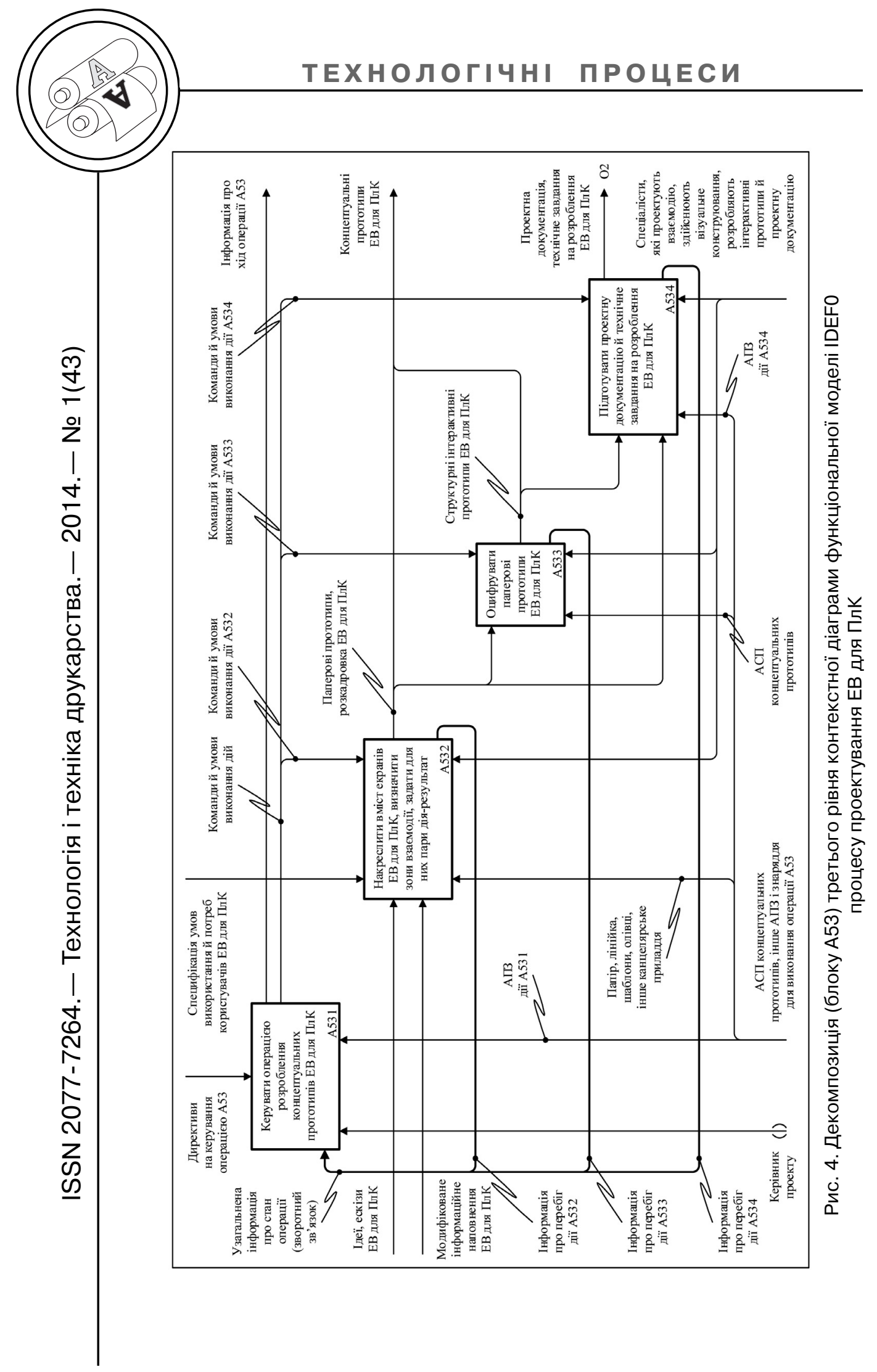

56 
потрібно для цього виконати стане четвертим рівнем ієрархічної структури IT проектування ЕВ для ПлК (див. рис. 4).

Дія А531. Протягом цієї дії керівник проекту зі створення ЕВ для ПлК дає команди й визначає умови виконання дій усієї операції.

Дія А532. Протягом цієї дії група, залучених до проектування спеціалістів, розробляє паперові прототипи ЕВ для ПлК й розкадровки (англ. storyboard, послідовність паперових прототипів, що описує поведінку користувача ЕВ для ПлК).

Дія А533. Протягом цієї дії проектувальники використовують АСП концептуальних прототипів для того, щоб перетворити паперові прототипи й розкадровки ЕВ для ПлК у структурні інтерактивні прототипи.

Дія А534. Протягом цієї дії група фахівців, залучених до проектування ЕВ для ПлК, здійснює оформленням необхідної документації для забезпечення процесу розроблення ЕВ для ПлК. Додаткову описову інформацію можуть створювати лише для паперових прототипів ЕВ для ПлК, якщо за результатами їх оцінювання прийнято рішення про те, що розробляти структурні інтерактивні прототипи ЕВ для ПлК немає потреби.

На рис. 4 показано, що керівник проекту зі створення ЕВ для ПлК виробляє команди й умови виконання дій (А532, A533, А534), а також приймає рішення (дія А531) про перехід від виконання однієї функції до іншої (черговість реалізації дій А532, A533, A534) на основі узагальненої описової інформації про стан операції А53. Цей зворотний зв'язок формує описова інформація про перебіг кожної дії (А532, А533, А534) порізно й забезпечує ітераційне виконання операції А53.

У підсумку, на основі методології функціонального моделювання штучних систем IDEF0 було розроблено IT проектування EВ для ПлК. Доцільність реалізації IT зумовлена зниженням трудомісткості процесів використання інформаційних ресурсів у результаті застосування сучасної обчислювальної техніки. Детально розглянуто компоненти IT, в яких відбувається перетворення інформації. Вони представлені функціональними блоками на діаграмах (див. рис. 4). На цих рисунках також видно взаємодію IT із зовнішнім середовищем (стрілки позначають об'єкти управління, апаратно-програмні засоби автоматизації тощо). Запропонована IT $€$ цілісною системою, що здатна забезпечити вирішення задач проектування ЕВ для ПлК із використанням можливостей своїх компонентів. Для розробленої IT проектування ЕВ для ПлК легко забезпечити динамічний розвиток. 3 часом її можна модифікувати, додавати нові компоненти, а головне - змінювати структуру, яка показує внутрішню організацію, взаємозв'язки компонентів системи (рис. 5). 


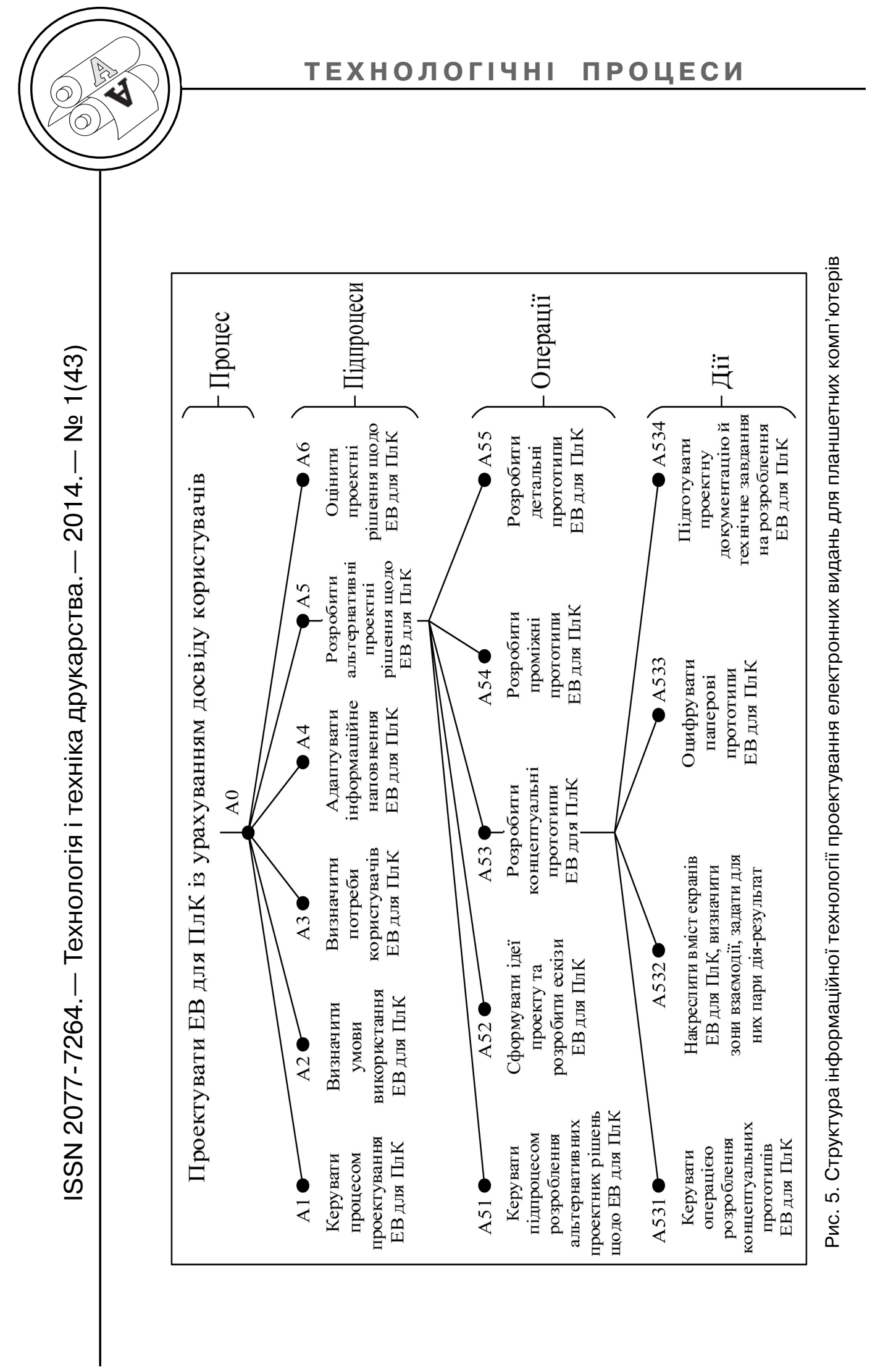

58 


\section{Висновки}

у результаті дослідження здійснено декомпозицію (блоку А5) другого й (блоку А53) третього рівня контекстної діаграми функціональної моделі IDEFO процесу проектування ЕВ для ПлК. Виділено такі функціональні блоки другого рівня декомпозиції: A51 - керувати підпроцесом розроблення альтернативних проектних рішень щодо ЕВ для ПлК, А52 - сформувати ідеї проекту та розробити ескізи ЕВ для ПлК, А53 розробити концептуальні прототипи ЕВ для ПлК, А54 - розробити проміжні прототипи ЕВ для ПлК, А55 - розробити детальні прототипи EB для ПлК. Перелік функціональних блоків третього рівня декомпозиції наступний: А531 - керувати операцією розроблення концептуальних прототипів ЕВ для ПлК, А532 - накреслити вміст екранів ЕВ для ПлК, визначити зони взаємодії, задати для них пари дія-результат, А533 - оцифрувати паперові прототипи EB для ПлК, А534 - підготувати проектну документацію й технічне завдання на розроблення ЕВ для ПлК. Детально розглянуто функції (позначені блоками) й об'єкти (позначені стрілками) діаграм декомпозиції другого й третього рівнів контекстної діаграми функціональної моделі IDEFO процесу проектування ЕВ для ПлК.

Розроблено структуру IT проектування EB для ПлК. Структура показує внутрішню організацію, взаємозв'язки компонентів системи. Запропонована IT складається з ієрархічно впорядкованих компонентів, а саме: процесу (AO), підпроцесів (A1A6), операцій (A51A55) і дій (А531А534). У підсумку, на основі методології функціонального моделювання штучних систем IDEF0 розроблено IT проектування ЕВ для ПлК.

Актуальним продовження проведеного дослідження вважаємо розроблення АСП концептуальних прототипів EB для ПлК.

\section{Список використаної літератури}

1. Пушкар О. І. Мультимедійні видання : навч. посіб. / О. І. Пушкар, В. Є. Климнюк, В. В. Браткевич. - Х. : Вид-во ХНЕУ, 2012. - 142 с.

2. Вуль В. А. Электронные издания / В. А. Вуль. - СПб. : БХВПетербург, 2003. $-560 \mathrm{c}$.

3. Гасов В. М. Методы и средства подготовки электронных изданий : учеб. пособ. / В. М. Гасов, А. М. Цыганенко. - М. : МГУП, 2001. - 735 с.

4. Киричок Т. Ю. Електронні видання : довід. / уклад. Т. Ю. Киричок. - К. : НТТУ «КП।», 2010. - 400 c.

5. Піх І. В. Інформаційні технології моделювання видавничих процесів : навч. посіб. / І. В. Піх, В. М. Сеньківський. - Львів : Укр. акад. друкарства, 2013. $-220 \mathrm{c}$.

6. Сеньківський В. М. Автоматизоване проектування книжкових видань : моногр. / В. М. Сеньківський, Р. О. Козак. - Львів : Укр. акад. друкарства, 2008. -224 c.

7. Ратушняк Ю. В. Функціональна модель процесу проектування електронних видання для планшетних комп'ютерів / Ю. В. Ратушняк // Полігр. і вид. справа. - 2013. - № 12(6162). - С. 4151. 
8. Р 50.1.0282001. Информационные технологии поддержки жизненного цикла продукции. Методология функционального моделирования. Введ. впервые; Введ. 20020701. - М. : Изд-во стандартов, 2001. - 54 с. (Рекомендации по стандартизации).

9. Integration definition for function modeling (IDEF0) [Електронний ресурс]. - Режим доступу : http://www.idef.com/pdf/idef0.pdf.

\section{References}

1. Pushkar O. I. Multymediini vydannia : navch. posib. / O. I. Pushkar, V. le. Klymniuk, V. V. Bratkevych. - Kh. : Vyd-vo KhNEU, 2012. - $142 \mathrm{~s}$.

2. Vul' V. A. Jelektronnye izdanija / V. A. Vul'. — SPb. : BHV Peterburg, 2003. $-560 \mathrm{~s}$.

3. Gasov V. M. Metody i sredstva podgotovki jelektronnyh izdanij : ucheb. posob. / V. M. Gasov, A. M. Cyganenko. - M. : MGUP, 2001. - 735 s.

4. Kyrychok T. lu. Elektronni vydannia : dovid. / uklad. T. lu. Kyrychok. - K. : NTTU «KPI», 2010. - $400 \mathrm{~s}$.

5. Pikh I. V. Informatsiini tekhnolohii modeliuvannia vydavnychykh protsesiv : navch. posib. / I. V. Pikh, V. M. Senkivskyi. - Lviv : Ukr. akad. drukarstva, 2013. $-220 \mathrm{~s}$.

6. Senkivskyi V. M. Avtomatyzovane proektuvannia knyzhkovykh vydan : monohr. / V. M. Senkivskyi, R. O. Kozak. — Lviv : Ukr. akad. drukarstva, 2008. $224 \mathrm{~s}$.

7. Ratushniak lu. V. Funktsionalna model protsesu proektuvannia elektronnykh vydannia dlia planshetnykh komp'iuteriv / lu. V. Ratushniak // Polihr. i vyd. sprava. - 2013. - № $12(6162)$. - S. 4151.

8. R 50.1.028 2001. Informacionnye tehnologii podderzhki zhiznennogo cikla produkcii. Metodologija funkcional'nogo modelirovanija. - Vved. vpervye; Vved. 200207 01. - M. : Izd-vo standartov, 2001. - 54 s. - (Rekomendacii po standartizacii).

9. Integration definition for function modeling (IDEFO) [Elektronnyi resurs]. - Rezhym dostupu : http://www.idef.com/pdf/idef0.pdf.

Разработка моделей, методов и программного обеспечения для автоматизации процесса проектирования электронных изданий для планшетных компьютеров является актуальной задачей. Осуществлена декомпозиция (блока А5) второго и (блока А53) третьего уровня контекстной диаграммы функциональной модели IDEFO процесса проектирования электронных изданий для планшетных компьютеров. Подробно рассмотрены функции (обозначены блоками) и объекты (обозначены стрелками) диаграмм декомпозиции. Разработана структура информационной технологии проектирования электронных изданий для планшетных компьютеров. Структура показывает внутреннюю организацию, взаимосвязи компонентов системы. Предложенная информационная технология состоит из иерархически упорядоченных компонентов, а именно: процесса (A0), подпроцессов (A1A6), операций (A51A55) и действий (A531 A534).

Ключевые слова: электронное издание; информационная технология; планшетный компьютер; процесс проектирования; структура; функциональная модель; IDEFO. 
The development of models, methods and software to automate the process of designing the electronic editions for tablet computers is an important task. The second (box A5) and third (box A53) level decomposition of functional IDEFO model context diagram of designing the electronic editions for tablet computers has been done. The functions (boxes) and objects (arrows) of decomposition diagrams have been considered. The information technology structure of designing the electronic editions for tablet computers has been developed. The structure shows the internal organization and relations of the system components. Information technology consists of hierarchically ordered components: process (A0), subprocesses (A1A6), operations (A51A55) and actions (A531A534).

Keywords: electronic edition; information technology; tablet computer; designing process; structure; functional model; IDEFO.

Рецензент - О. М. Величко, д.т.н., професор, НТУУ «КПІ» 